\title{
Analysis of BOD and COD levels for home industry wastewater: A case study in a sewage streams
}

\author{
Nelius Harefa ${ }^{1, *}$, Arifman Gulo ${ }^{1}$ and Saronom Silaban ${ }^{2}$ \\ ${ }^{1}$ Department of Chemistry Education, Faculty of Teacher Training and Education, Universitas Kristen \\ Indonesia, Jakarta 13630, Indonesia \\ ${ }^{2}$ Department of Chemistry, Universitas Negeri Medan, Medan 20221, Indonesia \\ *Corresponding author: NH, nelius.harefa@uki.ac.id
}

DOI: 10.24114/jpkim.v13i1.24142

Article history:

Received: 04 March 2021

Revised: 23 March 2021

Accepted: 24 March 2021

Abstract: Environmental pollution caused by waste is pollution that very dangerous for living things. In particular, water pollution, waste that is disposed of through waterways will disrupt the water ecosystem which will have an impact on human life. On the other hand, the development of entrepreneurship such as home industry has a positive impact on society, especially in terms of the economy. Therefore, water pollution indicators are needed that can be used as guidelines in treating wastes such as BOD and COD. In this study, analyzed the levels of BOD and COD from home industry wastewater in the Cawang area. The home industry includes laundry, cracker business, restaurants, printing houses, photocopying, and snack businesses. Based on the results of data analysis, the highest BOD level was 45.827 in samples taken at night. And, the highest COD levels were 95.923 in samples taken at night. These data indicate that the levels of BOD and COD in the water in the home industry waste disposal sites are below the standard threshold for wastewater quality. The levels of $B O D$ and $C O D$ are in the safe category for aquatic biota.

Keywords: BOD levels, COD levels, Waste, Water pollution

\section{Introduction}

Water pollution is pollution that is very dangerous for living things, especially aquatic biota. This pollution can damage aquatic ecosystems that affect human life. Water pollution inevitably occurs along with the times and technology. The byproducts of various products that can be utilized will generally be waste which has the potential to pollute water. These wastes are very dangerous for the environment if they are not treated according to procedures. These wastes generally contain various pollutants and have the potential to pollute water including groundwater 
(Nurhalisa \& Hasin, 2017; Nasution \& Silaban, 2017; Putra \& Yulia, 2019; Aji \& Jailani, 2020; Harefa \& Silaban, 2020; Widiarti \& muryani, 2020).

Community activities play an important role in waste production. Community activities, especially those related to the treatment of waste, affect waste production and in efforts to handle it (Dewi et al. 2016; Siburian et al. 2017). This situation shows that water pollutants can come from various sources such as office activities (Sulistia \& Septisya, 2020) and even activities in housing (Suoth, 2016). Home industry activities can also contribute to water pollution, especially if it is not treated wisely (Esta et al. 2016). In general, determinants can affect water pollution (Setianto \& Fahritsani, 2019).

Water pollution caused by waste production is important to observe regularly. There are various indicators of water pollution that can be used as a reference for determining policies and anticipatory measures so that pollution can be controlled, including the Biochemical Oxygen Demand (BOD) and Chemical Oxygen Demand (COD) of the water (Supenah et al. 2015; Nurhalisa et al. . 2017; Rachman et al. 2017; Barus, 2019). These two indicators indicate the quantity of oxygen in the water which is related to the content of organic matter in the water (Kustiasih, 2011). Therefore, analysis of BOD and COD levels must be carried out to determine the level of pollution that occurs and is used as a quality standard for wastewater (Atima, 2015; Andika et al. 2020).

Water BOD and COD levels are actually influenced by several factors, one of which is time variation (Susilo et al. 2016; Santoso, 2018). Generally, the longer the waste is dispersed in water, the lower the BOD and COD levels in the water. In addition, particle size can affect the levels of BOD and COD in the water (Mustafa et al. 2020). Therefore, it is important to carry out continuous monitoring (Firdaus et al. 2018) and a pro-active attitude of the community in controlling the use of products that have the potential to become polluting waste. Decreasing BOD and COD levels at certain measurements are not necessarily an indicator in general, because BOD and COD levels are very dynamic.

In general, high BOD and COD levels can have a negative impact on the environment (Soukotta et al. 2019). Therefore, efforts are needed to minimize the increase in BOD and COD levels. In addition to efforts to control waste production, the community can carry out other efforts such as the use of aquatic plants (Kriswandana, 2018) and stimulus to increase seaweed (Dewa, 2016). Utilization of seaweed contributed positively to the reduction of BOD and COD levels in water. In addition to the use of seaweed, the use of rice husk ash has been proven effective in reducing levels of BOD and COD in water (Budiman \& Amirsan, 2015). In addition, treatment of waste such as reprocessing before disposal can affect the impact of this waste (Nuraini et al. 2019).

Another effort that can be done in an effort to reduce water BOD and COD levels is optimization of wastewater treatment plants (Sasiang et al. 2019). This effort is a 
modern effort that is effective in reducing water BOD and COD levels, especially if implemented optimally. However, this effort requires great effort and effort, so it requires the collaboration of several parties such as local governments and active waste producing organizations such as companies.

Water pollution actually causes harm to society. Water can be intended to support human activities other than as one of the basic needs (Mustafa et al. 2020). Water can be used for irrigation in rice fields (Saputra et al. 2020), plantations, and various other agricultural activities. Apart from agriculture, water is the main support in the plantation sector and various fields related to the utilization of other resources. Therefore, the community must play an active role in maintaining water quality. The community must be at the forefront of efforts to control waste, which is a source of water pollution. This control can be started from the smallest scale such as controlling household waste.

\section{Methods}

The research sample was taken from wastewater streams of people who have several home businesses including laundry, crackers, restaurants, printing houses, photocopying, and snacks in the Cawang area, East Jakarta. Samples were taken at a disposal outlet which is about 50 meters from the residents' last house. Samples were taken at 5 points (samples $\mathrm{X}_{1}, \mathrm{X}_{2}, \mathrm{X}_{3}, \mathrm{X}_{4}$, and $\mathrm{X}_{5}$ ) in the morning, day and night. The experimental procedure is as shown in Fig 1.

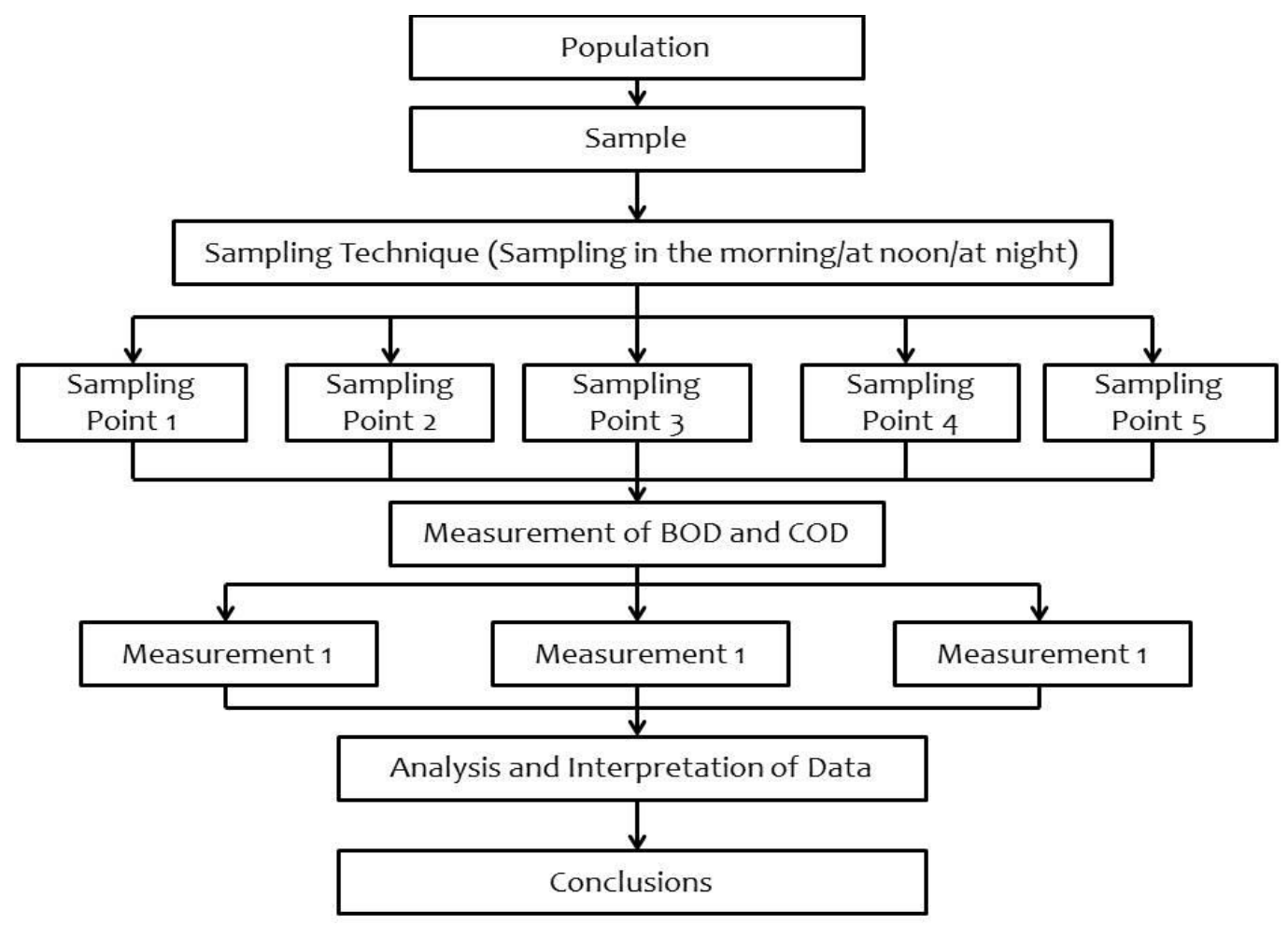

Fig 1. Research procedure 
The research was conducted in November 2020 - February 2021. The research stages consisted of the observation stage and the analysis stage. The observation stage includes observing the types of businesses occupied by residents in the vicinity of the sampling site and observing the use of river water by residents as well as interviews with several residents related to changes that have occurred at the river. The analysis stage includes the preparation and content analysis of the sample (Bahagia et al. 2020). The samples were measured BOD and COD as an indicator of water pollution. Measurements were carried out in the chemistry laboratory, Christian University of Indonesia using the Portable DO and BOD meter HI98193 for BOD measurement and the Suntex TR-1100 COD Thermoreactor for COD measurement.

\section{Results and Discussion}

Samples were taken in the morning, afternoon, and evening which consisted of 5 points of collection. The sample was prepared beforehand before measuring BOD and COD. The results of the sample BOD measurement are as in Table 1.

Table 1

BOD Measurement Results

\begin{tabular}{|c|c|c|c|c|c|c|c|c|c|}
\hline \multirow[b]{2}{*}{$\begin{array}{c}\text { Sa } \\
\text { mpl } \\
\text { e }\end{array}$} & \multicolumn{3}{|c|}{ Sampling in the morning } & \multicolumn{3}{|c|}{ Sampling at noon } & \multicolumn{3}{|c|}{ Sampling at night } \\
\hline & $\begin{array}{c}\text { Measur } \\
\text { ement } \\
1\end{array}$ & $\begin{array}{c}\text { Measur } \\
\text { ement } \\
2\end{array}$ & $\begin{array}{c}\text { Measur } \\
\text { ement } \\
3\end{array}$ & $\begin{array}{c}\text { Measur } \\
\text { ement } \\
1\end{array}$ & $\begin{array}{c}\text { Measur } \\
\text { ement } \\
2\end{array}$ & $\begin{array}{c}\text { Measur } \\
\text { ement } \\
3\end{array}$ & $\begin{array}{c}\text { Measur } \\
\text { ement } \\
1\end{array}$ & $\begin{array}{c}\text { Measur } \\
\text { ement } \\
2\end{array}$ & $\begin{array}{c}\text { Measur } \\
\text { ement } \\
3\end{array}$ \\
\hline $\mathrm{X} 1$ & 22.02 & 22.04 & 22.02 & 11.13 & 11.12 & 11.13 & 41.87 & 42.01 & 42.03 \\
\hline$X_{2}$ & 22.04 & 22.05 & 22.01 & 11.09 & 11.12 & 11.12 & 42.01 & 42.01 & 42.05 \\
\hline$x_{3}$ & 22.03 & 22.03 & 22.03 & 11.08 & 11.08 & 11.08 & 42.01 & 41.97 & 41.97 \\
\hline$X_{4}$ & 22.14 & 22.15 & 22.14 & 11.22 & 11.22 & 11.22 & 45.78 & 45.88 & 45.82 \\
\hline$X_{5}$ & 22.12 & 22.14 & 22.14 & 11.20 & 11.19 & 11.20 & 45.68 & 45.70 & 45.70 \\
\hline
\end{tabular}

Measurement of BOD samples was carried out 3 times for each sample. The results of these three measurements are averaged so that the cumulative measurements for each sample taken in the morning, afternoon, and evening are obtained. The comparison of the average sample BOD measurement results is shown in Fig 2.

Based on Fig 2, the highest BOD is in the samples taken at night, while the lowest BOD is in the samples taken during the day. After measuring of BOD levels, COD measurements were taken on the prepared samples as in Table 2.

COD measurement of the sample was carried out 3 times for each sample. The results of these three measurements are averaged so that the cumulative measurements for each sample taken in the morning, afternoon, and evening are obtained. The comparison of the average sample COD measurement results is shown in Fig 3. 


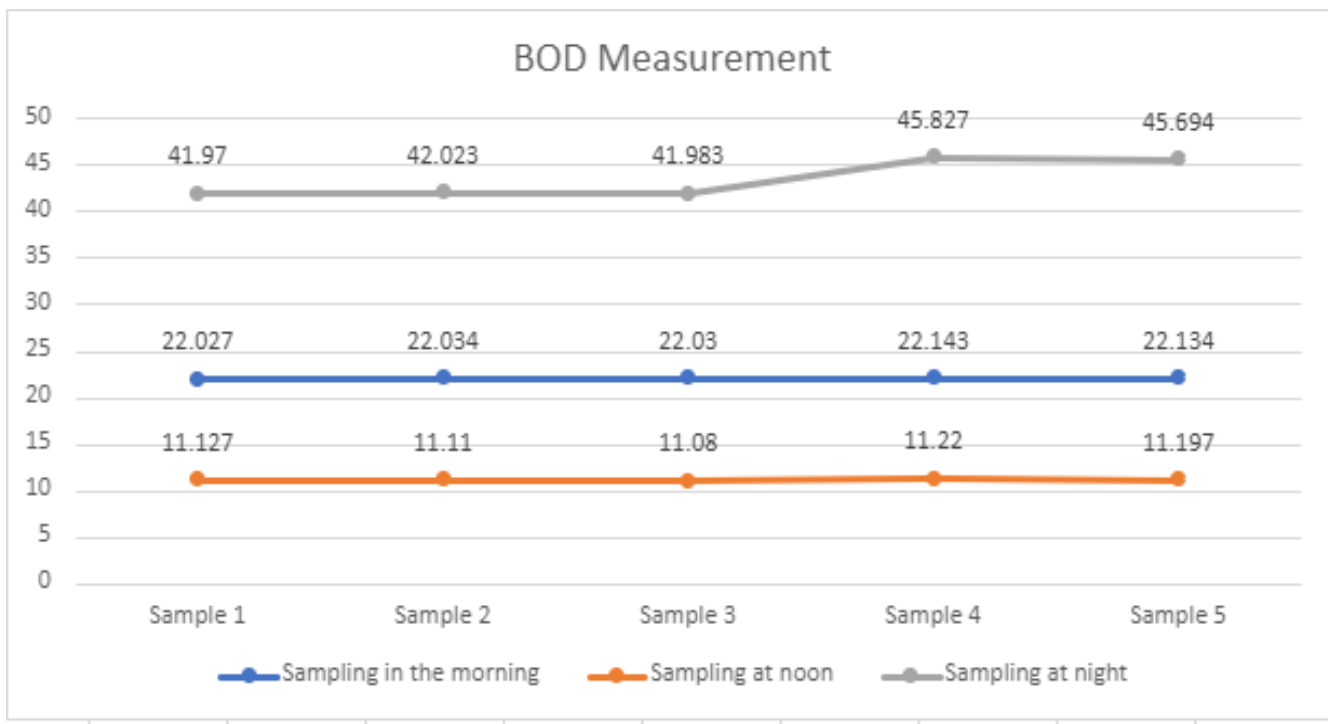

Fig 2. Comparison of average BOD measurement results

Table 2

COD measurement results

\begin{tabular}{c|c|c|c|c|c|c|c|c|c}
\hline \multirow{2}{*}{$\begin{array}{c}\text { Sa } \\
\text { mpl } \\
\text { e }\end{array}$} & \multicolumn{2}{|c|}{ Sampling in the morning } & \multicolumn{3}{c|}{ Sampling at noon } & \multicolumn{3}{c}{ Sampling at night } \\
\cline { 2 - 10 } & $\begin{array}{c}\text { Measur } \\
\text { ement }\end{array}$ & $\begin{array}{c}\text { Measur } \\
\text { ement }\end{array}$ & $\begin{array}{c}\text { Measur } \\
\text { ement }\end{array}$ & $\begin{array}{c}\text { Measur } \\
\text { ement }\end{array}$ & $\begin{array}{c}\text { Measur } \\
\text { ement } \\
\mathbf{2}\end{array}$ & $\begin{array}{c}\text { Measur } \\
\text { ement } \\
\mathbf{2}\end{array}$ & $\begin{array}{c}\text { Measur } \\
\text { ement } \\
\mathbf{1}\end{array}$ & $\begin{array}{c}\text { Measur } \\
\text { ement } \\
\mathbf{2}\end{array}$ & $\begin{array}{c}\text { Measur } \\
\text { ement } \\
\mathbf{3}\end{array}$ \\
\hline $\mathrm{X}_{1}$ & 72.83 & 72.83 & 72.82 & 31.05 & 31.07 & 31.08 & 91.66 & 91.68 & 91.68 \\
\hline$X_{2}$ & 72.88 & 72.86 & 72.84 & 31.19 & 31.18 & 31.19 & 92.05 & 92.06 & 92.02 \\
\hline$X_{3}$ & 72.82 & 72.82 & 72.82 & 31.20 & 31.18 & 31.18 & 92.01 & 92.07 & 92.07 \\
\hline$X_{4}$ & 73.22 & 73.24 & 73.22 & 31.86 & 31.88 & 31.87 & 95.87 & 95.98 & 95.92 \\
\hline$X_{5}$ & 73.02 & 73.04 & 73.04 & 31.70 & 31.76 & 31.75 & 95.35 & 95.32 & 95.30 \\
\hline
\end{tabular}

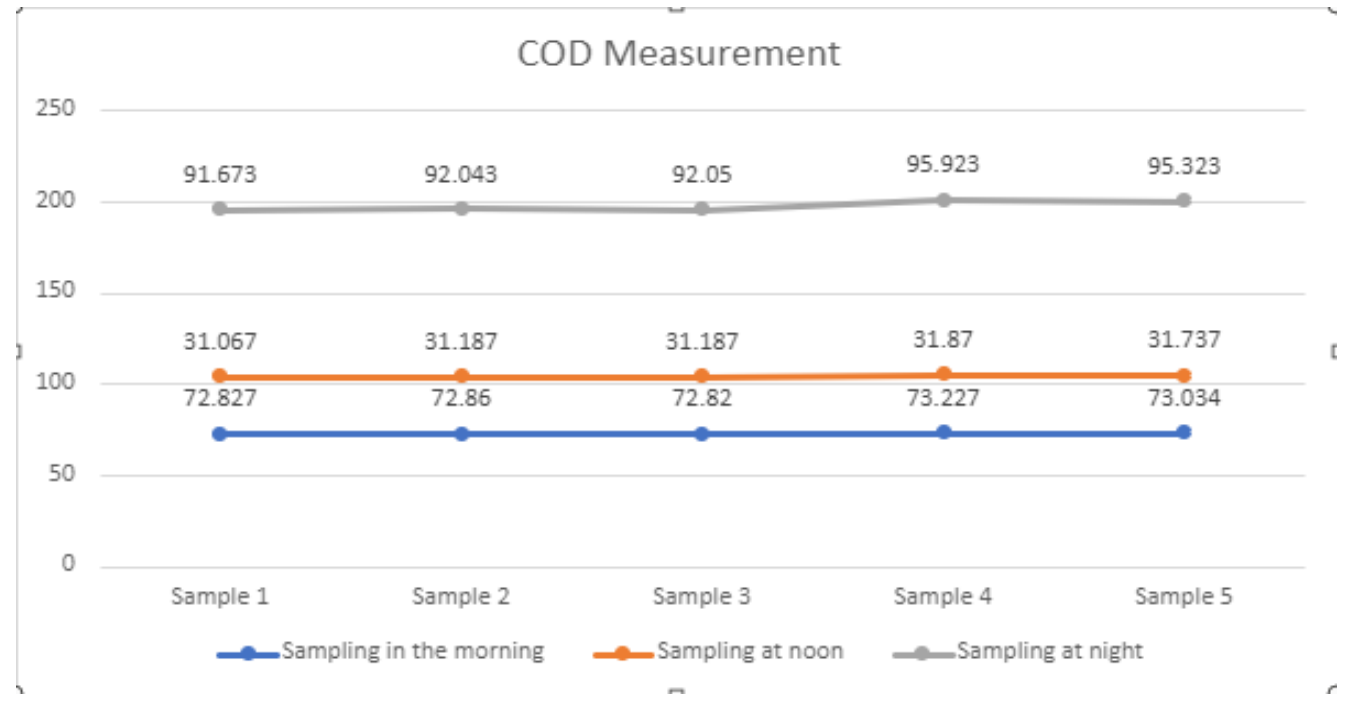

Fig 3. Comparison of average COD measurement results for samples 
Based on Fig 3, the highest COD in samples taken at night, while the lowest COD in samples taken during the day. After the measurement, the levels of BOD and COD are interpreted according to the BOD and COD thresholds regarding the wastewater quality standard (Peraturan Menteri Lingkungan Hidup Republik Indonesia Nomor 5 Tahun 2014) as in Table 3.

Table 3

Interpretation of BOD and COD Measurement Results

\begin{tabular}{|c|c|c|c|c|c|c|c|}
\hline \multirow{2}{*}{\multicolumn{2}{|c|}{ Sample }} & \multicolumn{3}{|c|}{ BOD Levels } & \multicolumn{3}{|c|}{ COD Levels } \\
\hline & & $\begin{array}{c}\text { BOD } \\
(\mathrm{mg} / \mathrm{L})\end{array}$ & $\begin{array}{l}\text { Threshold } \\
\mathrm{s}(\mathrm{mg} / \mathrm{L})\end{array}$ & $\begin{array}{c}\text { Categor } \\
y\end{array}$ & $\begin{array}{c}\text { COD } \\
(\mathrm{mg} / \mathrm{L})\end{array}$ & $\begin{array}{c}\text { Threshold } \\
\mathrm{s}(\mathrm{mg} / \mathrm{L})\end{array}$ & Category \\
\hline \multirow{3}{*}{$\mathrm{X}_{1}$} & $\begin{array}{l}\text { Sampling in } \\
\text { the morning }\end{array}$ & 22.027 & 75 & Safety & 72.827 & 180 & Safety \\
\hline & $\begin{array}{l}\text { Sampling at } \\
\text { noon }\end{array}$ & 11.127 & 75 & Safety & 31.067 & 180 & Safety \\
\hline & $\begin{array}{l}\text { Sampling at } \\
\text { night }\end{array}$ & 41.970 & 75 & Safety & 91.673 & 180 & Safety \\
\hline \multirow{3}{*}{$X_{2}$} & $\begin{array}{l}\text { Sampling in } \\
\text { the morning }\end{array}$ & 22.034 & 75 & Safety & 72.860 & 180 & Safety \\
\hline & $\begin{array}{l}\text { Sampling at } \\
\text { noon }\end{array}$ & 11.110 & 75 & Safety & 31.187 & 180 & Safety \\
\hline & $\begin{array}{l}\text { Sampling at } \\
\text { night }\end{array}$ & 42.023 & 75 & Safety & 92.043 & 180 & Safety \\
\hline \multirow{3}{*}{$x_{3}$} & $\begin{array}{l}\text { Sampling in } \\
\text { the morning }\end{array}$ & 22.030 & 75 & Safety & 72.820 & 180 & Safety \\
\hline & $\begin{array}{l}\text { Sampling at } \\
\text { noon }\end{array}$ & 11.080 & 75 & Safety & 31.187 & 180 & Safety \\
\hline & $\begin{array}{l}\text { Sampling at } \\
\text { night }\end{array}$ & 41.983 & 75 & Safety & 92.050 & 180 & Safety \\
\hline \multirow{3}{*}{$X_{4}$} & $\begin{array}{l}\text { Sampling in } \\
\text { the morning }\end{array}$ & 22.143 & 75 & Safety & 73.227 & 180 & Safety \\
\hline & $\begin{array}{l}\text { Sampling at } \\
\text { noon }\end{array}$ & 11.220 & 75 & Safety & 31.870 & 180 & Safety \\
\hline & $\begin{array}{l}\text { Sampling at } \\
\text { night }\end{array}$ & 45.827 & 75 & Safety & $95 \cdot 923$ & 180 & Safety \\
\hline \multirow{3}{*}{$X_{5}$} & $\begin{array}{l}\text { Sampling in } \\
\text { the morning }\end{array}$ & 22.134 & 75 & Safety & 73.034 & 180 & Safety \\
\hline & $\begin{array}{l}\text { Sampling at } \\
\text { noon }\end{array}$ & 11.197 & 75 & Safety & 31.737 & 180 & Safety \\
\hline & $\begin{array}{l}\text { Sampling at } \\
\text { night }\end{array}$ & 45.694 & 75 & Safety & 95.323 & 180 & Safety \\
\hline
\end{tabular}

Based on table 3, BOD and COD of home industry wastewater in the morning, afternoon, and evening collection are below the BOD and COD thresholds according 
to the Regulation of the Minister of Environment of the Republic of Indonesia Number 5 of 2014 concerning wastewater quality standards. These data indicate that the river water of the home industry waste disposal in the Cawang area is in the safe category.

The research sample was taken 3 times, namely in the morning, during the day, and at night. The sampling points at each sampling were 5 locations. This sampling technique is carried out based on predictions of community activities in treating waste (Susilo et al. 2016; Harefa, 2018) as well as based on observations and interviews conducted with several residents. In the morning, the majority of people carry out activities in order to prepare products to be marketed. During the day, the community provides services to consumers. And at night, people sort products, clean equipment, and make decisions about products that cannot be recycled.

Based on Fig 2, the highest BOD is found in samples taken at night. Of the five sampling points, the samples taken at night showed higher levels than the samples taken in the morning or during the day. This data shows that the majority of residents who have home industry businesses treat waste at night. Meanwhile, the lowest BOD data were obtained in samples taken during the day. These data indicate that waste disposal activities during the day tend to decrease compared to waste disposal activities at night or in the morning.

Likewise in COD measurement, based on Fig 3, the highest COD levels were found in samples taken at night. The data for the five samples showed that the COD levels at the times of the home industry waste disposal sites in the Cawang area were higher than the COD levels in the samples taken in the morning and during the day. This data shows that the majority of residents treat waste at night. Meanwhile, the lowest COD levels were found in samples taken during the day. The data show that the treatment of waste (waste disposal) during the day is less than at night and during the day.

However, based on Table 3, the BOD and COD levels of all samples taken at night, morning and afternoon were below the threshold. Based on the Regulation of the Minister of Environment of the Republic of Indonesia Number 5 of 2014 concerning Wastewater Quality Standards, the Cawang community home industry waste disposal times are in the safe category. Even so, residents are expected to be proactive in reducing waste production through activities to reduce the quantity of products that have the potential to produce waste and activities that are reconstructive in nature in the form of utilizing products that will turn into waste into reusable products. In addition, continuous education is needed so that residents have knowledge in an effort to minimize waste production. In general, community activities greatly determine waste products that have a massive impact on water pollution or not (Dewi et al. 2016; Siburian, 2017). 


\section{Conclusion}

Home industry actually has a positive impact on society, especially in terms of income and opportunities. Based on these positive impacts, the government of the Republic of Indonesia supports and facilitates the formation of a home industry by providing a platform and policies that favor small and medium enterprises such as the home industry. With this support and facilities, the government hopes the formation of new entrepreneurs who can support the country's economy. However, in addition to positive impacts, the development of entrepreneurship such as home industry actually has a negative impact, especially on the environment. By-products from products that can be used generally will become waste that can pollute the environment, especially if not treated inappropriately. There are many indicators of environmental pollution that can be analyzed, including the levels of BOD and COD at the time of the waste disposal. This pollution indicator shows the dissolved oxygen content to stabilize the organic material that is present chemically as well as the oxygen content needed to stabilize the organic matter that is biologically present. Based on the analysis of the research data, it shows that the BOD and COD levels in the sample are below the threshold in the safe category.

\section{References}

Aji, M. T., \& Jailani, A. Q. (2020). Studi kualitas air tanah kota magelang akibat dampak limbah domestik dan industri. Journal of Aquaculture Science,5(2), 120-128. DOI: 10.31093/joas.v5i2.122

Andika, B., Wahyuningsih, P., \& Fajri, R. (2020). Penentuan nilai BOD dan COD sebagai parameter pencemaran air dan baku mutu air limbah di pusat penelitian kelapa sawit (PPKS) Medan. QUIMICA: Jurnal Kimia Sains dan Terapan, 2(1), 14-22.

Atima, W. (2015). BOD dan COD sebagai parameter pencemaran air dan baku mutu air limbah. BIOSEL (Biology Science and Education): Jurnal Penelitian Science dan Pendidikan, 4(1), 83-93. DOI: 10.33477/bs.v4i1.532

Bahagia, B., Suhendrayatna, S., \& Ak, Z. (2020). Analisis tingkat pencemaran air sungai Krueng Tamiang terhadap COD, BOD dan TSS. Jurnal Serambi Engineering, 5(3). DOI: 10.32672/jse.v5i3.2073

Barus, B. R. (2019). Analisa kualitas limbah cair rumah sakit Sembiring, Deli Tua. Jurnal Inovasi Kesehatan Masyarakat, 1(1), 39-47. DOI: 10.36656/jikm.v111.192

Budiman, B., \& Amirsan, A. (2015). Efektifitas abu sekam padi dan arang aktif dalam menurunkan kadar BOD dan COD pada limbah cair industri tahu super afifah kota Palu. Healthy Tadulako Journal (Jurnal Kesehatan Tadulako), 1(2), 23-32.

Dewa, R. P. (2016). Penanganan baku mutu kualitas air limbah produksi Atc dari rumput laut Eucheuma cottonii. Majalah BIAM, 12(2), 34-40. DOI: 10.29360/mb.v12i2.1963

Dewi, I., Wahab, I., \& Citra, F. W. (2016). Analisis kualitas air akibat bongkar muat batu bara di sungai Ketahun desa pasar Ketahun kecamatan Ketahun Kabupaten Bengkulu Utara. Jurnal Georafflesia: Artikel Ilmiah Pendidikan Geografi, 1(2), 61-81. 
Esta, K. A., Suarya, P., \& Suastuti, N. G. D. A. (2016). Penentuan status mutu air Tukad Yeh Poh dengan metode storet. Jurnal Kimia (Journal of Chemistry). DOI: 10.24843/JCHEM.2016.v10.io1.pog.

Firdaus, M. I., Saptomo, S. K., \& Febrita, J. (2018). Evaluasi kinerja unit instalasi pengolahan air limbah Bojongsoang Bandung. Jurnal Teknik Sipil dan Lingkungan, 3(1), 35-48. DOI: 10.29244/jsil.3.1.35-48

Harefa, N. (2018). Sensitivitas ligan ditizon terhadap absorbsi logam zink dengan teknik emulsi membran cair. Jurnal EduMatSains, 3(1), 57-68.

Harefa, N., \& Silaban, S. (2020). Identification of metal content in food using gravimetric and iodometric methods: The case on children's food. Jurnal Pendidikan Kimia, 12(2), 52-61. DOI: 10.24114/jpkim.v12i2.19395

Kriswandana, F. (2018). Pemanfaatan tanaman air untuk menurunkan kadar BOD dan COD dalam limbah cair rumah potong hewan. Gema Lingkungan Kesehatan, 16(3). DOI: 10.36568/kesling.v16i3.898

Kustiasih, T. (2011). Penentuan angka kebutuhan oksigen kimia air limbah dengan mempertimbangkan faktor ketidakpastian. Jurnal Permukiman, 6(3), 121-128.

Mustafa, M., Rahim, M., Irwan, M., \& Sari, D. P. (2020). Pengaruh ukuran partikel bentonit alam teraktivasi pada penurunan limbah cair sarung tenun Samarinda. MEDIA PERSPEKTIF: Journal of Technology, 12(1), 01-09. DOI: 10.46964/jtmp.v12i1.376

Nasution, H. I., \& Silaban, S. (2017). Analisis logam berat Pb dan Cd dalam air sumur di sekitar lokasi pembuangan sampah akhir. Jurnal ITEKIMA, 1(1), 18-24.

Nuraini, E., Fauziah, T., \& Lestari, F. (2019). Penentuan nilai BOD dan COD limbah cair inlet laboratorium pengujian fisis politeknik ATK Yogyakarta. Integrated Lab Journal, 7(2).

Nurhalisa, N., \& Hasin, A. (2017). Analisis kadar COD dan BOD pada air sumur akibat buangan limbah pabrik tapioka di kec. Pallangga Kab. GOWA. Jurnal Media Laboran, 7(2), 22-27.

Peraturan Menteri Lingkungan Hidup Republik Indonesia Nomor 5 Tahun 2014 tentang Baku Mutu Air Limbah.

Putra, A. Y., \& Yulia, P. A. R. (2019). Kajian kualitas air tanah ditinjau dari parameter pH, nilai COD dan BOD pada Desa Teluk Nilap Kecamatan Kubu Babussalam Rokan Hilir Provinsi Riau. Jurnal Riset Kimia, 10(2), 103-109. DOI: 10.25077/jrk.v10i2.337

Rachman, H. A., Andina, L., \& Primanadini, A. (2017). Penentuan chemical oxygen demand (COD) pada air sungai Martapura akibat limbah industri tekstil sasirangan. In Prosiding Seminar Nasional dan Presentasiilmiah Perkembangan Terapi Obat Herbal Pada Penyakitdegeneratif (Vol. 1, No. 1).

Santoso, A. D. (2018). Keragaan nilai DO, BOD dan COD di Danau Bekas Tambang Batubara studi kasus pada danau sangatta North PT. KPC di Kalimatan Timur. Jurnal Teknologi Lingkungan, 19(1), 89-96. DOI: 10.29122/jtl.v19i1.2511

Saputra, I. G. D., Sumiyati, S., \& Sucipta, I. N. (2020). Kualitas air pada irigasi subak di Bali. Jurnal BETA (Biosistem dan Teknik Pertanian), 8(2), 257-265. DOI: 10.24843/JBETA.2020.v08.io2.pog

Sasiang, E., Maddusa, S. S., \& Sumampouw, O. J. (2019). Efektivitas instalasi pengolahan air limbah berdasarkan parameter biological oxygen demand, chemical oxygen demand dan derajat keasaman di rumah sakit umum GMIM Pancaran Kasih Manado. KESMAS, 8(6). 
Setianto, H., \& Fahritsani, H. (2019). Faktor determinan yang berpengaruh terhadap pencemaran sungai musi kota Palembang. Media Komunikasi Geografi, 20(2), 186-198. DOI: $10.23887 / \mathrm{mkg} . v 20 i 2.21151$

Siburian, R., Simatupang, L., \& Bukit, M. (2017). Analisis kualitas perairan laut terhadap aktivitas di lingkungan pelabuhan Waingapu-Alor Sumba Timur. Jurnal Pengabdian Kepada Masyarakat, 23(1), 225-232. DOI: 10.24114/jpkm.v23i1.6639

Soukotta, E., Ozsaer, R., \& Latuamury, B. (2019). Analisis kualitas kimia air sungai Riuapa dan dampaknya terhadap lingkungan. Jurnal Hutan Pulau-Pulau Kecil, 3(1), 86-96.

Sulistia, S., \& Septisya, A. C. (2020). Analisis Kualitas Air Limbah Domestik Perkantoran. Jurnal Rekayasa Lingkungan, 12(1).

Suoth, A. E. (2016). Karakteristik Air limbah rumah tangga pada salah satu perumahan menengah keatas di Tangerang Selatan. Ecolab, 10(2), 80-88. DOI: 10.20886/jklh.2016.10.2.80-88

Supenah, P., Widiastuti, E., \& Priyono, R. E. (2015). Kajian kualitas air sungai condong yang terkena buangan limbah cair industri batik trusmi cirebon. Majalah Ilmiah Biologi BIOSFERA: A Scientific Journal, 32(2), 110-118. DOI: 10.20884/1.mib.2015.32.2.302

Susilo, F. A. P., Suharto, B., \& Susanawati, L. D. (2016). Pengaruh variasi waktu tinggal terhadap kadar BOD dan COD limbah tapioka dengan metode rotating biological contactor. Jurnal Sumberdaya Alam dan Lingkungan, 2(1), 21-26.

Sutriati, A. (2011). Penilaian kualitas air sungai dan potensi pemanfaatannya studi kasus $S$. Cimanuk. Jurnal sumber daya air, 7(1), 1-17.

Widiarti, I. W., \& Muryani, E. (2020). Kajian kualitas air lindi terhadap kualitas air tanah di sekitar tpa (tempat pemrosesan akhir) sampah jetis, desa pakem, kecamatan gebang, purworejo, jawa tengah. Jurnal Tanah dan Air (Soil and Water Journal), 15(1), 1-9. DOI: 10.31315/jta.v1511.2721 